\title{
Faculty Development Structures and Activities in Ontario's Colleges of Applied Arts and Technology
}

\section{GLEN A. JONES* \& GEORGE L. GEIS ${ }^{\dagger}$}

\begin{abstract}
The paper presents a discussion of faculty development in 22 of Ontario's Colleges of Applied Arts and Technology. We report the findings of a survey which collected information on administrative structure, funding, mandate, faculty development activities, publication, incentives for faculty participation, assessment of faculty needs and evaluation. We conclude by raising a number of questions which faculty developers might address as changes in the social, political and economic environment present new challenges to colleges and universities.
\end{abstract}

\section{Résumé}

Ce document se penche sur le développement du corps professoral de 22 Collèges d'arts appliqués et de technologie de l'Ontario. Nous vous présentons les résultats d'une enquête qui a été menée pour recueillir des renseignements sur les structures administratives, le financement, le développement du corps professoral, les publications, les mesures visant à encourager la participation du corps professoral, ainsi que l'évaluation du corps professoral et de ses

\footnotetext{
* Associate Professor, Higher Education Group, Ontario Institute for Studies in Education.

$\dagger$ Professor, Higher Education Group, Ontario Institute for Studies in Education.

An earlier version of this paper was presented at the Tenth Annual Conference on Teaching and Learning in Higher Education, McGill University, June 16-19, 1990. The authors wish to acknowledge the generous support and assistance of the various faculty development officials who participated in this study. Funding for the project was provided by the OISE Small Scale Grants program.
} 
besoins. Et en terminant, nous soulevons plusieurs questions auxquelles les responsables du développement du corps professoral devraient s'adresser à la lumière des nouveaux défis que représentent l'évolution des structures sociales, politiques et économiques pour les collèges et les universités.

\section{Introduction}

One of the characteristics of a professional is continuing, lifelong education and development. Often this activity has been seen as self-initiated and self-managed. More recently, however, organized continuing development programs have been centrally mounted (e.g., by the employer organization or professional association). Nowhere has the surge of professional development been more evident than in faculty development. In the 1960's and 70's, a large number of faculty development centres were founded on college and university campuses to carry out developmental activities for, or in cooperation with, faculty members (Centra, 1976; Donald, 1974; Donald \& Shore, 1976).

In this paper we will discuss faculty development issues and report on a study designed to develop an inventory of faculty and instructional development in twenty-two colleges. The study provides an overview of several aspects of faculty development at these institutions: structure, funding, mandate, activities, publications, incentives, needs assessment, and evaluation of professional development activities. We will conclude with a discussion of a number of questions which faculty developers might address as changes in the socio-political environment present new challenges to colleges and universities.

\section{The Context For Faculty Development}

The professor has a somewhat ambiguous professional status. Normally the attributes which characterize a professional are seen in his or her discipline preparation and activities. As a teacher, the professor typically lacks those characteristics. There is little formal preparation for the activities of teaching; there are no certification or licensing requirements, and only rarely are professors members of a professional organization representing the teaching aspects of their lives. Many professors identify as professionals in their discipline; they are first chemists or biologists and secondarily teachers. This is particularly paradoxical since most professors are identified by others as teachers and spend most of their time in matters related to teaching.

The pressures and rewards for maintaining current expertise in one's discipline are usually quite powerful. Corresponding motivational incentives for teaching are lacking. Consequently, in large part faculty development has addressed the latter aspect of the professor's life. 
Centra (1989) contends that "there is little question that teaching improvement has been the major focus of most faculty development efforts, but programs have also included such activities as career counselling and professional writing improvement programs" (p. 168). It is true that the term "professional development", when used to describe many of the activities of campus centres, has primarily referred to the teaching rather than to the scholarly side of the professor's professional life. Indeed, most centres were established in response to the call for improved instruction: to assist the professor in developing more effective ways of teaching. On the other hand, with an aging, locked-in professoriate, this may be changing. Some centres seem to be attending to the continued career growth and development of faculty. ${ }^{1}$ Weimer (1990) argues that although "faculty development started out meaning the enhancement of teaching skill (it) soon became a more inclusive term connoting a broad range of professional activities, from support for scholarship to counselling on personal problems ... that impinge on professional effectiveness" (p. xv).

It should be noted that the term "teaching" has often been interpreted rather narrowly to refer to the classroom performance of the professor. This definition slights the many other activities that constitute a complete picture of instruction (e.g., evaluation, course design, mentoring). While faculty developers may opt for the broader definition, many of their potential clients may not.

\section{The Focus of Faculty Development}

At whom or what are faculty development efforts being addressed, and what evidence is there that there is a problem which needs to be dealt with in this way? Various concerns or problems seem to have fueled the faculty development movement. In the early decades of its evolution, student concern with the quality of teaching was a major factor. Coupled with this was a growing recognition that "management" had at least some responsibility for encouraging the continued development of staff. There was also a call for increased visible recognition of the importance of teaching on campus. In recent years the focus seems to have shifted, as noted above, to address the perceived need for faculty revitalization.

Vaguely stated purposes such as these encourage different interpretations. Assuming that students in the 1960's were calling for improved instruction might lead one to focus on such activities as program and course redesign and to the installation of new technologies of teaching. If the interpretation was that students in fact were attending to the vital role evaluation played in their career, the improvement of testing procedures would be the focus. If, and this seems to have been a common interpretation, students were complaining about the classroom 
performance of teachers, then the thrust would be to develop better teaching skills among faculty members and to design methods of evaluating that teaching.

Furthermore, even when the "problem" has been explicated the target of the solution efforts may not be self-evident. Traditionally, the role of the professor has been one of great autonomy and independence, and the perception of the professor as a unique container of content expertise, has led to development activities usually directed at individual professors. Symptomatic of opting for this focus on the individual professor is the increased prevalence of terms such as "faculty development" replacing such terms as "instructional improvement." In order to create a better teaching establishment, the emphasis has been placed on strengthening the individual building blocks of the foundation.

It is important to note that this is not the only valid view of the professional development client in higher education. For example, an equally valid focus would be on programs or departments. The fact that the emphasis has usually been placed on the individual professor reveals our commonly held perceptions of instruction and the unit of teaching (i.e., the professor's course), but this may be one of the less effective strategies in attempting to change the instructional function in a university or college. A broader focus on instructional events, rather than classroom performance of an instructor, and on programs of study, rather than courses, may be an equally or more effective strategy.

When the professor is the focus of the development activity, a sohisticated strategy must address more than simply the specifics of classroom performance. As early as 1975 , Bergquist and Phillips sounded a theme, echoed in later literature, that there are at least three kinds of professional development activities: organizational, instructional and personal. Faculty developers have been encouraged to consider the complexity of improving teaching and to develop broad programs addressing the many needs and facets of the professional.

Without a clear mission, the development activities may be almost whimsically determined. Without a demonstrable concern or problem, one that is clearly supported by evidence and understood by all, persuading the stakeholders to join the development efforts may be difficult, and, of course, the determination of success in reaching the mission goals will be almost impossible.

Most of the research on faculty development has focussed on universities and four-year colleges. However, the community college with its special commitment to teaching is a particularly interesting site for the study of faculty development. 


\section{The Ontario Colleges of Applied Arts and Technology}

The surge of interest in faculty development in the 1960s occurred at about the same time as Ontario's non-degree sector was being transformed with the creation of Colleges of Applied Arts and Technology (CAATs). The Ontario government created a unique network of institutions designed to provide technical/vocational and adult education in order to address the skilled manpower needs of a highly industrialized province. ${ }^{2}$ Each institution is a "crown corporation", governed by provincial regulation and by its college governing board, primarily composed of members appointed by a provincial intermediary body, the Council of Regents (Dennison \& Gallagher, 1986; Jones, 1994).

There is little articulation between the CAATs and the provincial universities, and credit transfer is generally left to the discretion of the various institutions (Skolnik, 1990; Skolnik \& Jones, 1993). Except for sectoral expansion and a few minor modifications, the basic structure of the sector changed very little in the first twenty years (Jones, 1991) though the system is now evolving in a number of policy areas in response to recommendations from a sector-wide review (Vision 2000, 1990). The sector is currently composed of 23 institutions, ${ }^{3}$ each of which, generally speaking, serves a geographic region of the province. The sector employs approximately 8400 full-time faculty and operates some 2000 different post-secondary programs (Stokes, 1989).

The CAATs are one of the two sectors in Ontario's binary higher education "system". While there are broad similarities in terms of the role, structure and function of universities in all Canadian provinces, one can argue that the structures and functions which define the non-university/community college sector(s) are unique in each province (Skolnik, 1986). While there are obvious structural differences between jurisdictions, the one characteristic shared by all of these institutional types is a central concern for teaching (Dennison \& Gallagher, 1986). As teaching-focused, postsecondary institutions, community colleges face similar challenges related to the professional development of faculty.

The founders of the Ontario college system knew that many of the faculty would be drawn from the appropriate trades, industries and technologies; thus, novice welders would be taught by master welders. This suggested that the colleges should establish units which would at least orient new faculty to the world of teaching. Since colleges were conceived of as being highly responsive to the needs of the community, particularly the labour market needs, it was foreseen that faculty would regularly be developing new courses and programs (Ontario Department of Education, 1967). Consequently they would need skills in such areas as course design and evaluation, and in-house faculty development was seen from the outset as a relatively important function in the colleges. 
This study is an attempt to offer a snapshot of faculty development units and activities in the CAAT sector. A look earlier or later in time would likely reveal a somewhat different picture. In carrying out this study we had several purposes in mind. First, we wanted to provide an overview and an inventory of several aspects of faculty development at these institutions: structure, funding, mandate, activities, publications, incentives, needs assessments, and evaluation of professional development activities across this large system of community colleges. We were interested in how these activities were organized, what they consisted of, and so on. Second, we wanted to reflect the obtained portrait against existing portraits of such activities elsewhere. Third, we wanted to provide a platform for a discussion of several generic issues about faculty development, indicating their relevance to this site and conversely, using the data from this site to illuminate more general points.

Our interest has been encouraged by a heightening of interest in human resource development in the college system. An aging professoriate, ${ }^{4}$ the diminution of the natural enthusiasm that accompanied the founding of the system, possible changes in the role of the colleges, the pressure for greater efficiency in times of financial restraint, an increase in the number of academically unprepared or disadvantaged students, and the need to recruit students by demonstrating that the college faculty are effective teachers, all have contributed to this renewed attention to the colleges' human resources (Giroux, 1989; Vision 2000, 1990).

While this paper focuses on institution-based activities, it is important to recognize that there are also regional and system-wide activities related to faculty development. ${ }^{4}$ The colleges have created four regional associations concerned with human resource development, Northern, Eastern, Western, and Central, and each group acts as a forum for discussion and information-sharing. Three of these regional associations commonly organize cooperative programs. Both the Eastern Region and the Western Region, for example, operate teacher training programs which are organized and funded by member-institutions. These programs include a combination of joint region-based activities and institution-based activities. The Central Region periodically organizes conferences. The four regional groups combine to form the College Committee on Human Resource Development, a provincial association of professional development officials.

The colleges have also created several province-wide activities. The InService Teacher Training Certificate Program, based at Confederation College, is a modularized program for upgrading college faculty. ${ }^{6}$ The Association of Colleges of Applied Arts and Technology of Ontario initiated a system of competitive grants to support projects and activities under its program: Human Resource Development in the Third Decade. 
College faculty are unionized under a province-wide collective agreement, and this agreement has considerable impact on professional development activities. The agreement establishes guidelines for faculty sabbaticals, specifies the minimum number of professional development days, and includes an instructional assignment formula.

\section{Procedures and Limitations}

An interview questionnaire was devised after a review of the literature on faculty development. A draft questionnaire was reviewed by the College Committee on Human Resource Development, and members' comments and suggestions were incorporated into the final version. The Committee also identified an individual from each college who, they believed, would be in the best position to respond to the survey.

The interview questionnaire consisted of 20 questions addressing four major topic-areas: organization, resources, mandate, and activities. ${ }^{7}$ The questionnaire and a letter explaining the project were sent to each of the college faculty development officers so that they could prepare for a telephone interview. The interviews were conducted between October 31st and December 18th, 1989, and each took from 30 to 70 minutes to complete. All 22 colleges participated in the study, and all respondents were extremely cooperative; many were enthusiastic.

A summary of each interview was prepared and returned to the respondent so that errors of fact or omission could be noted. This component of the study was completed by February of 1990. Many respondents also provided additional materials such as program brochures, faculty handbooks, and annual reports.

There are three major limitations associated with these procedures that should be noted. The first is that the survey data presents a snapshot of faculty development structures and activities which were in place at the time of the interview, but our discussions with respondents suggest that these units are regularly changing and evolving. Several colleges, for example, have reorganized their professional development departments since the interviews were completed. Second, the data are based on the perceptions of a single individual in each institution, the person chiefly responsible for the faculty development program. Somewhat different responses might have been obtained if the questions had been directed to college presidents, faculty members, or other interested parties. Finally, the study was designed to obtain information on activities which are organized at a central level in each college, and we have obtained only a general sense of the nature and structure of the activities which are organized by individual departments or campuses. 


\section{Results}

\section{Structure}

The faculty development structures of the 22 colleges present a confusing array of reporting lines and terminology, richly coloured by the various operating philosophies and personalities involved in these units, and blurred by periodic restructuring of operations through shifting administrative responsibilities and the creation or elimination of staff positions. While there is tremendous diversity in terms of the specific structural details of the professional development units, they share many characteristics. All colleges, for example, operate some form of faculty development program, and the responsibility for college-wide activities is traditionally assigned to an individual at the third level of the organizational hierarchy of the college, that is, the person responsible for the program usually reports to a Vice President.

While this study deals specifically with faculty development, it is important to note that most colleges (19 of 22) view such activities as a subset of a much broader range of programs, often referred to as human resource development. These units provide services to support staff and managers, as well as faculty, and this operating model has obvious implications for the way these units are organized. While a unit may assign responsibility for faculty development to a single individual, that individual works closely with those who operate support staff and management development programs, and so such units must consider all employee groups when determining unit plans and budgetary priorities. On the other hand, three colleges have structurally separated faculty development from other staff development initiatives, and created administrative units which link faculty-directed activities with other endeavours, such as program and curriculum development.

In terms of faculty development, most colleges (20 of 22) divided responsibilities between a central unit and local departments or campuses. The central unit is responsible for college-wide programs, often centering on the development of basic teaching and learning skills. Such programs are designed to meet the needs of the college as a whole. Local units are assigned responsibility for faculty development in terms of subject-area or campus-specific needs. A central unit, for example, might organize an activity on the general topic of evaluating student work, while a nursing unit might organize an activity on the topic of evaluating the clinical practice of nursing students. Only one college organizes all activities at a central level, while one other college, which has virtually eliminated its centralized operations for budgetary reasons, only operates programs at the local level. 
Most colleges (16 of 22) have some form of centralized standing committee structure in place and a wide variety of supporting committee structures were found. Eight colleges have a committee composed of faculty, support staff and managers which discusses the professional development needs and policies for all college employees. Other colleges have separate faculty development committees, often as part of a triad of committees representing the major employee groups. Three institutions operate both types of committees, usually with separate faculty, support staff, and manager committees which periodically combine to form a joint committee on professional development. While most committees are advisory, four have been assigned some level of executive authority over a specific budget area, or over some area of college policy. The committee structure sometimes provides a formal linkage between the central unit and the academic divisions. In one college the central committee is composed of the local-unit professional development coordinators; in others, committee members are chosen to represent specific academic constituencies such as program divisions or campuses.

The survey responses reveal a variety of staffing patterns and arrangements. Most colleges have full-time employees assigned to the central unit, though there are a plethora of different job titles and descriptions. In some cases faculty members are seconded to the unit, often acting as teaching consultants. Larger units tend to have a combination of full-time and part-time staff, with some division of responsibility within the unit. Several have created campusbased positions for organizing and supervising both college-wide and campusspecific programs.

Most colleges operate workshops and seminars, and a variety of arrangements are used to facilitate and staff these activities. Many colleges make extensive use of volunteers, and occasionally pay for external speakers or workshop facilitators. Some colleges provide support to college staff who provide assistance, subject to the provisions of the collective agreement. In some cases, providing a workshop or seminar is a requirement for those faculty who obtain financial support to engage in a specific activity, such as independent research or participation in a conference.

\section{Funding}

All colleges provide financial support for faculty development, though it was difficult to determine the total level of support available for these activities. In most colleges, funds are assigned to both the central unit and to the local departments or campuses, and many respondents did not have detailed information on department budgets for faculty development. Funds assigned to the central unit 
are often used to provide services to faculty, staff, and managers, and it is not easy to isolate expenditures relating specifically to faculty programming. There are also a variety of budgeting and fund-accounting systems in place, making it extremely difficult to obtain parallel, and therefore comparable, data.

In ten colleges the amount available for professional development is determined, in whole or in part, by formula. Units receive a dollar-amount per staff member (ranging from approximately $\$ 30$ to $\$ 246$ per faculty member), an amount based on a percentage of all salaries (ranging from $1 \%$ to $11 / 3 \%$ ), or an amount based on a percentage of the college budget (1\% in two cases). Twelve units request and receive funding through the college's budget process. In at least four colleges there was some combination of formula-based and budgetbased allocation, usually reflecting the different ways in which funds are assigned to central and local units. Several respondents indicated that there are large variations in their budgets from year to year, often related to the number of new faculty which are hired by the college.

At the time of the interviews, many of the colleges were applying for grants under the provincial Human Resource Development in the Third Decade program. Except for that specific initiative, only five colleges reported receiving support from some external source, such as government support for programs where French is the language of instruction, government grants for regional activities or research projects, or gifts of equipment from industry.

\section{Mandate}

Eighteen colleges reported that there was, or would soon be, some form of institutional mission statement or mandate for professional development. Such statements tend to emphasize the development of all staff, rather than just faculty, and to indicate general, rather than specific, missions or goals. The following examples typify these general statements of mission or philosophy:

\section{COLLEGE A:}

...to meet the continual need to upgrade individual job skills and professional competencies, develop and improve interpersonal relationships and develop and maintain a sense of worth and contribution within and without the college. The staff development program is for everyone at the college: faculty, support personnel and administrators. Both the goals of the college and the goals of the individual are served through the acquisition and application of new skills and information. 


\section{COLLEGE B:}

...plan professional development activities and find resources to meet the needs of College staff.

Two respondents referred to an implied mandate, an unwritten understanding of the professional development mission. Nineteen stated that professional development was, in some way, referenced in their institution's strategic plan.

\section{Activities}

All colleges operate some form of teacher training or orientation for new faculty, either on their own or in cooperation with other institutions in their region (Table 1 ). ${ }^{8}$ These programs generally include a pre-service component, which provides training in basic teaching skills, and inservice programs and support during the initial two-year probationary period. At least thirteen colleges operate some form of program directed specifically to part-time faculty. ${ }^{9}$ In many cases this is a one or two day training session for new instructors.

Eighteen colleges also organize periodic workshops or seminars on a variety of topics during the year. In addition, many organize a program of activities for specific professional development days or weeks, somewhat resembling a miniature conference. These workshops address a variety of teaching-related subjects,

Table 1

Common college-wide faculty development activities

Activity Type $\quad \mathrm{N}$

New Teacher Training/Orientation $\quad 22$

$\begin{array}{ll}\text { Periodic Workshops/Seminars } & 18\end{array}$

Program of Workshops/Seminars $\quad 13$

Specific Program for Part-Time Faculty 13

Whole or Partial Payment of University/College Fees 11

Tuition Waiver or Nominal Fee for Courses at Own College $\quad 7$

Individual Consultation/Assistance $\quad 7$

Facilitates Faculty Exchanges/Secondments 5

Facilitates Faculty Participation in Graduate Programs 5

Financial Support for Conference Participation 4

Annual Conference $\quad 4$

Back-to-Industry Program for Faculty Renewal 4 
as well as more generic topics of interest to the broader college community, such as instruction in the use of computer software or retirement planning.

Seven colleges indicated that they provide individual assistance to faculty who have teaching-related problems or concerns. Such assistance might include class visits and informal evaluation of teaching, or referring faculty to other college services or resources. One respondent stated that the unit occasionally provides a formal evaluation of teaching where there is some dispute between the perceptions of the faculty member and the chair.

Four colleges encourage faculty to obtain short-term industry-based positions as a method of renewing field-based knowledge and experience. One college, for example, has a policy requiring all faculty to obtain relevant positions in an industrial or organizational environment, for a six to eight week period, once every three years.

Other types of activities included special programs for "experienced" faculty, support for faculty initiated projects/research, computer purchase plans which include a training component, and assisting faculty with the development of the individual professional development plans required in some colleges.

Respondents also indicated that a variety of activities are organized and funded at the department level, in addition to those described above. The local unit is often the source of conference and travel funding and tuition assistance; some organize workshops and conferences.

\section{Publication}

Most professional development units produce some form of publication. Fourteen publish annual reports, and eight produce a regular newsletter which is distributed to staff. Most units advertise their activities by distributing brochures and flyers. Other types of publication include regular contributions to the college newspaper, abstracts of professional development resources, employee handbooks, and, in one case, a newsletter on computer applications.

\section{Incentives For Faculty Participation}

Many colleges have programs or policies designed to encourage faculty participation in development activities. In sixteen institutions, new full-time faculty are required to participate in the college's teacher training/orientation program as a condition of their probationary contract. Eleven respondents indicated that college policies concerning tuition waivers, rebates, or reductions provide faculty with an incentive to participate in college or university courses. Five colleges have awards for excellence in teaching, and four have awards or programs to recognize participation in professional development activities. At least one 
institution pays part-time faculty when they participate in the part-time teacher training program. Three colleges also stated that their back-to-industry programs involve a financial incentive, since participants sometimes receive salaries from both the college and industry while they are working in the field, subject to the provisions of the campus policy.

Several respondents also described their student evaluation programs as incentives for faculty participation in development activities. Faculty who receive negative evaluations of their teaching from students will often seek out programs and workshops that will provide them with assistance in terms of teaching skills.

\section{Assessing Faculty Needs}

Almost all respondents reported that they regularly seek information on faculty needs. Eighteen colleges conduct formal surveys of faculty in order to determine needs. Most of these surveys are administered annually, while some institutions administer surveys every two to five years. Ten respondents emphasized the important role that committees play in providing information on this topic, and two indicated that they meet periodically with academic managers to discuss the needs of department staff. One college occasionally organizes focus groups to discuss specific need-related issues. Nineteen respondents emphasized the importance of informal contact with faculty, staff, and managers as a method of obtaining information on faculty needs.

\section{Evaluation}

Most colleges make at least some attempt to evaluate professional development activities, though such evaluation is often limited to the review of feedback questionnaires distributed at the conclusion of specific workshops and programs. Several respondents questioned the utility of feedback questionnaires, except as a method of providing feedback to the workshop facilitator. Others use survey responses as a basis for programming decisions. Nineteen colleges use feedback questionnaires on a regular basis.

Four respondents stated that operation reviews or task forces had provided valuable information on the strengths and weaknesses of their professional development programs. Such reviews often include the collection and analysis of evaluative data, and they provide a forum for discussing the future direction of faculty development activities. One college reported that its professional development committee conducts an annual review of activities as part of its planning process. 
Other respondents evaluate their activities by collecting data on participation, sitting-in on workshops, analyzing information from other college surveys (e.g., employment equity surveys), informal discussion with faculty, or interviewing chairs to obtain feedback on teacher training programs. Three respondents stated that there is no formal program or process for the evaluation of faculty development activities at their college.

\section{Summary}

Each of the 22 Colleges of Applied Arts and Technology included in this study operates some form of faculty development program, and 21 of these institutions have some central unit or office responsible for college-wide programs. Most of these units tend to view faculty development as a subset of a broader range of activities designed to address the needs of all staff; many have standing committees which review or discuss these programs. There is variety among the colleges in terms of the structure and funding of these units. All colleges are members of a provincial professional development body, and one of four regional groups.

Most respondents indicated that there was, or soon would be, some form of institutional mission statement concerning professional development. In terms of activities, all colleges provide some form of teacher training/orientation program for new full-time faculty, and these programs traditionally involve a preservice component and some form of follow-up during the probationary period. Most colleges also organize a variety of workshops and seminars during the year, many of which deal with teaching-related topics. In addition to these nondegree-oriented activities, many colleges operate some sort of program through which faculty can apply for tuition reimbursement if they successfully complete a university or college credit course. In some colleges, the faculty development unit provides individual assistance to faculty who request help. Centralized faculty development activities are often supplemented by initiatives at the local (e.g., departmental) level. Most units make at least some attempt to assess the needs of faculty, and to evaluate the specific programs that they offer.

\section{Discussion}

We noted earlier some of the pressures which are working to challenge and perhaps change the shape of faculty development activities for the next decade. In addition to the general continuing trend for greater accountability, the CAATs face a recent move to cross-provincial standardization which may take the form of uniform tests being used in similar programs at different colleges. 
This study was not evaluative; we do not propose to end with a criticism of the current state of faculty development at the colleges. Rather, by way of trying to be helpful and as a means of posing some general questions for consideration by those in faculty development, we offer this self-evaluation checklist.

\section{How well planned and systematic is the faculty development effort?}

Faculty development has been repeatedly criticized for being unsystematic and scattered in its efforts (e.g., Dennison and Gallagher, 1986). While responsiveness to clients is a key feature of most programs, if the activities are only reactive and not driven by a clear set of mission goals, the results are likely to reflect the weakness of this unfocussed approach.

\section{Are the mission goals of the program clearly related to and reflective of: organizational goals?}

While the unit mounting the program may specify mission goals that seem appropriate to it, those goals should be aligned to the broader goals of the institution or it will risk being excellent but irrelevant. Academic institutions are notoriously neglectful of the development of clear and guiding statements of purpose. Rather than bemoan the lack of precise direction "from the top", the developers might proactively instigate the generation of more clearly defined institutional goals by indicating the need to align their unit goals with the institution's.

\section{Is the faculty development program located high up on the organization chart and does it have full, visible support of key administrators?}

Nelsen (1979) points out that

...faculty development programs require strong administrative leadership at the proper times. They always require strong administrative support. But "support" means not simply budget allocations; it means commitment, appreciation, and recognition. Taking time to openly express appreciation to an individual faculty member for his or her personal development efforts and contributions can have a profound and lasting impact. Rewarding faculty who have contributed to both personal and institutional renewal provides a strong sign to faculty generally. The administrative stance toward faculty development is quickly perceived and continually watched (p. 149).

Rather than being seen as an isolated and adjunctive function designed to shape up the faculty (somewhat like a faculty health club) the development efforts ideally should become an integral part of the broader organization as it attempts to move to what is currently being called a "learning organization". There are certainly examples in the CAAT system of continuing and successful attempts to 
tie the mission of staff development to those of the whole organization and to lend it strong, visible high-level support.

Today's development questions ask not simply how to improve one faculty member's teaching skills but how to revitalize tenured-in departments as a whole, how to create entirely new career options for faculty, how to reformulate the curriculum to attract new student populations, and how to keep the institution alive and competitive (Bland \& Schmitz, 1988, p. 191).

\section{How stable is the unit?}

Evidence from this survey suggests that on some campuses, the units were often, even constantly, in flux. To the extent that the very existance of the unit is continually at risk, planning is discouraged and likely to be irrelevant. If the unit is clearly perceived to be addressing the mission goals of the institution, however, greater stability is likely.

\section{To what extent are available resources coordinated and shared?}

Particularly in a "system" such as the CAATs one might expect extensive interaction and sharing among staff development units on the various campuses. To some extent this seems to be true. Given the relatively small budgets of most development units in colleges and universities such coordination among them seems very important. At the same time the attention to local interests and needs should not be diminished by such cooperative efforts. To some degree professional development efforts are always likely to remain idiosyncratic.

The CAATs offer examples of such cooperation. They have created four regional associations concerned with human resource development that act as forums for discussion and information sharing and organize cooperative programs. The regional groups combine to form the College Committee on Human Resource Development, a provincial association of professional development officers. As noted earlier, the colleges have also created several province-wide activities such as the In-service Teacher Training Certificate Program based at Confederation College. The Association of Colleges of Applied Arts and Technology of Ontario initiated a system of competitive grants to support projects and activities under its program: Human Resource Development in the Third Decade.

\section{Are the means of recruiting and providing services to clientele appropriate?}

Some faculty development programs present what might be called physicanpatient models. The faculty member is seen as deficient with regard to certain 
skills and knowledge and the developer prescribes and sometimes administers appropriate treatment. Furthermore, the "treatment" may be at the lower level of intellectual stimulation (e.g., workshops on the use of overhead projectors). Geis and Smith (1989) have argued that since faculty members are adults and professionals, any recruiting or development activity directed toward them should reflect this. (For a broader discussion of overall strategies or models appropriate to the faculty and the institution, see Smith, 1992). The consignment of teaching improvement activities to the level of procedural skill building reinforces the perception that it is somehow less valuable, complex and important than the discipline of the professor - just a set of tricks for putting over the content more effectively.

Furthermore, the strategy of recruiting and dealing with each faculty member individually may not be the most appropriate one. There is much to be said for targeting the discipline, program or department.

One clear implication of (the) increasing professionalization of college teaching for faculty professional development programs may be a shift in the placement or source of development activities. Faculties who have a sense of professional status as teachers may be less likely to seek assistance "outside" the profession. My own experience tells me that in these cases teaching workshops and materials need to be more discipline-specific and less coordinated by people in a central professional development office. Also, professional development for teaching may inevitably shift its focus from campus programs to professional associations or even teachers' unions ... (Young, 1987, page 13).

Situating development programs in existing units or groupings may work to break down the isolation of the individual professor and create a community which directs attention of individuals to the larger institution. Professors need to see themselves, as Nelsen (1979) put it, as a "corporate entity - a faculty - not an amalgamation of individuals and departments" (p. 145). But the purpose of this amalgamation is not to turn the faculty into corporation people, rather, Nelsen emphasizes the need for building an intellectual community, a particularly important goal at a community college.

Programs at the CAATs usually have advisory councils that include members drawn from businesses and industries in the community. To the extent that these councils function well, the obvious target for improvement is the program, already recognized and defined by this structure. 


\section{To what extent are activities related to demonstrable needs?}

We suggest that the work of a development unit should reflect evaluation of client needs (as related to unit and organizational missions). That in turn would indicate the need for evaluation of faculty. This is a delicate matter on most campuses. A discussion of the problems associated with such evaluation would take us far beyond the scope of this paper. Nevertheless, without some process which validly explicates needs, the program may flounder. So-called "needs assessments" which are somewhat informally and erratically carried out on many campuses suffer from various weaknesses. One is the reliance on selfevaluation as the basis of perceived needs. Self evaluation may differ significantly from evaluations by others such as administrators or students (Centra, 1989). While Centra concludes that such evaluations seem adequate for diagnostic purposes and formative uses, he also states that "research has shown that faculty who need faculty development most frequently do not take part in institutional programs" (Centra, 1989, p. 173).

\section{Does professional development adequately evaluate itself?}

Without a clear mission statement or some description of expected outcomes and impact, the success of development efforts cannot be determined. Often, the financing of faculty development offices, like many other campus units, results from an essentially political process which may not require or honor hard data. ${ }^{9}$ However, the professional approach to development would require a degree of accountability. There is a dearth of research on effectiveness of programs in the faculty development literature (Levinson-Rose \& Menges, 1981; Weimer \& Lenze, 1991). When evaluation is reported it rarely goes beyond, for example, indications of user satisfaction or descriptions of the numerous activities that have been undertaken, the weakest sorts of measures (Kirkpatrick, 1976).

Over the years faculty development passed through different phases. At some sites "(faculty) development has evolved from a collection of ad hoc activities to a professional function ... (There has been) a shift in focus away from individual growth toward organizational learning" (Acebo and Watkins, 1988, p. 49). The end of a century seems to promote reflection. It seems appropriate to reconsider the strengths and weaknesses of faculty development programs, to reflect on new challenges to be faced and on how well any particular program is situated for the future. Rather than carry out such reflections in the abstract this paper has attempted to imbed a discussion of these matters in the context of a real set of existing programs in Ontario. 


\section{Notes}

1 See, for example, the recent centre at the University of Connecticut (Halvorson, Thibodeau \& McKenna, 1987).

2 The CAATs are one of the two sectors in Ontario's binary-structured higher education "system". While there are broad similarities in terms of the role, structure and function of universities in all Canadian provinces, one can argue that the structures and functions which define the non-university/community college sector(s) are unique in each province (Skolnik, 1986). With this in mind, it is extremely difficult to determine the degree to which the findings presented in this study are generalizable to other Canadian community college sectors without additional research, though we suspect that a number of the trends and issues discussed in this paper parallel the experience of other jurisdictions.

3 Only 22 colleges were in full operation at the time this study was conducted.

4 Faculty revitalization is quite a different goal than the one the founders of many faculty development centres were attempting to address; however, it is not an exclusive concern of the community colleges. It may be a universal concern in higher education. Bland and Schmitz comment: "Whether institutions are in need of renewal or not, whether faculty vitality should be an ongoing priority or not are no longer issues in question" (1988, p. 190).

5 Ontario is not alone in attempting to coordinate faculty development on a province-wide basis. British Columbia, for example, has been working towards the development of a province-wide system for some time.

6 The program is offered in cooperation with the Ontario Council of Regents for Colleges of Applied Arts and Technology and the Ontario Public Service Employees Union.

${ }^{7}$ Contact authors for a copy of this questionnaire.

8 For a description and discussion of teacher training in other post-secondary institutions see Centra (1978) and Geis, Wilburn and Mellor (1981).

${ }^{9}$ McLean (1978) provides a broader discussion of faculty development activities directed toward part-time faculty.

10 Gustafson \& Bratton note that "evaluation was not a factor ..." in the closing of many campus centres $(1984$, p.2).

\section{References}

Acebo, S.C., \& Watkins, A. (1988). Community college faculty development: Designing a learning organization. In V.J. Marsick (Ed.), New Directions in Continuing Education, no. 38, Enhancing staff development in diverse settings (pp. 49-61). San Francisco: Jossey-Bass Inc., Publishers.

Bergquist, W.H., \& Philips, S.R. (1975). Components of an effective faculty development program. Journal of Higher Education, 46, 177-209. 
Bland, C., \& Schmitz, C. (1988). Faculty vitality in review: Retrospect and prospect. Journal of Higher Education, 59(2), 190-224.

Boice, R. (1987). Is released time an effective component of faculty development programs? Research in Higher Education, 26(3), 311-325.

Centra, J.A. (1976). Faculty development practices in U.S. colleges and universities. Princeton, NJ: Educational Testing Service.

Centra, J.A. (1978). Types of faculty development programs. Journal of Higher Education, 49(2), 151-162.

Centra, J.A. (1989). Faculty evaluation and faculty development in higher education. In J. C. Smart (Ed.), Higher education handbook of theory and research, Volume $V$, New York: Agathon Press.

Conrad, C., \& Hammond, M. (1982). Cooperative approaches to faculty development. Community College Review, 10(2), 48-51.

Dennison, J.D., \& Gallagher, P. (1986). Canada's community colleges: A critical analysis. Vancouver: University of British Columbia Press.

Donald, J.G. (1974). Staff development: An overview of practices throughout Canada. Paper presented at the Annual Conference of the Association of Canadian Community Colleges, Winnipeg, November.

Donald, J.G., \& Shore, B.M. (1976). Annotated index to pedagogical services in Canadian colleges and universities. Montreal: Centre for Learning and Development, McGill University.

Geis, G.L., \& Smith, R.A. (1989). If professors are adults. The Journal of Staff Program and Organizational Development, 7(4), 155-163.

Geis, G.L., Wilburn, M., \& Mellor, G. (1981). Preparing for teaching in colleges and universities: In-service support in Canada and the United States. Studies in Higher Education, 6(1), 47-57.

Giroux, R.F. (1989). A blueprint proposal for human resource development in the third decade of the Ontario Colleges of Applied Arts and Technology. Toronto: Task Force on Human Resource Development in the Third Decade.

Gustafson, K., \& Bratton, B. (1984). Instructional improvement centers in higher education. Journal of Instructional Development, 7(2), 2-7.

Halvorson, P.L., Thibodeau, J.A., \& McKenna, P.G. (1987). Professional development: Whose agenda? Academe, (May-June), 15-18.

Jones, G.A. (1991). Modest modifications and structural stability: Higher education in Ontario. Higher Education, 21, 573-587.

Jones, G.A. (1994). Higher education policy in Ontario. In L. Goedegebuure, F. Kaiser, P. Maassen, L. Meek, F. van Vught, \& E. de Weert (Eds.), Higher education policy: An international comparative perspective (pp. 214-238). Oxford: Pergamon Press.

Kirkpatrick, D.L. (1976). Evaluation in training. In R.L. Craig \& L.R. Bittell (Eds.), Training and development handbook. New York: McGraw-Hill.

Levinson-Rose, J., \& Menges, R.J. (1981). Improving college teaching: A critical review of research. Review of Educational Research, 51(3), 403-434.

McLean, R. (1978). Professional development and the part-time faculty. Journal of the Association of Canadian Community Colleges, 2(1), 105-114. 
Nelsen, W.C. (1979). Faculty development: Prospects and potential for the 1980 s. Liberal education, 65(2), 141-149.

Nelsen, N.C. (1980). Faculty development: Prospects and potentials for the 1980's. Liberal Education, 65, 141-149.

Ontario Department of Education (1967). Colleges of Applied Arts and Technology Basic documents (3rd Edition). Toronto: Ontario Department of Education.

Skolnik, M.L. (1986). Diversity in higher education: The Canadian case. Higher Education in Europe, 11(2), 19-32.

Skolnik, M.L. (1990). Articulation between CAATs and universities in Ontario: Issues, problems, and prospects. In G.A. Jones (Ed.), Higher Education Group Annual 1990, (pp. 32-48). Toronto: Higher Education Group, Ontario Institute for Studies in Education.

Skolnik, M.L., \& Jones, G.A. (1993). Arrangements for coordination between university and college sectors in Canadian provinces. Canadian Journal of Higher Education, 23(3), 56-73.

Smith, G. (1992). Responsibility for staff development. Studies in Higher Education, 17(1), 27-41.

Stokes, P. (1989). College transfer revisited: A working paper. In Colleges and the educational spectrum (Vision 2000 Background Papers). Toronto: Council of Regents.

Vision 2000 (1990). Vision 2000: Quality and Opportunity. Toronto: Ontario Ministry of Colleges and Universities.

Weimer, M. (1990). Improving college teaching: Strategies for developing instructional effectiveness. San Francisco: Jossey-Bass Inc., Publishers.

Weimer, M. \& Lenze, L.F. (1991). Instructional interventions: A review of the literature on efforts to improve instruction. In J.C. Smart (Ed.), Higher education: Handbook of theory and research, Volume VII. New York: Agathon Press.

Young, R.E. (1987). Faculty development and the concept of "Profession". Academe, (May-June), 12-14. 